\title{
Jazz Influences in Chamber Musical Works created by Composers from Iaşi at the Beginning of the $21^{\text {st }}$ Century
}

\author{
AURELIA SIMION \\ "George Enescu” National University of Arts Iaşi \\ ROMANIA*
}

\begin{abstract}
Chamber Music has always been a genre predefined to a certain audience. At the merge of the $20^{\text {th }}$ and $21^{\text {st }}$ Centuries, the interest for this genre has grown exponentially, from Romanian and Bessarabia composers alike. Because the concept of Chamber Music has evolved during the ages and has always offered the possibility for experimentation, it has managed to infiltrate into present day Ensembles, by associating timbre and constructive heterogenic instruments. The search for new ways of expressing oneself, new sounds and new stylistic methods and the desire to use new types of sound emission represent a continuous motivation for the composers, whose contribution to the Chamber Ensembles is frequently enrichened. Thus, the Jazz influence has a significant role inside the works of Sabin Pautza, Romeo Cozma (Romania) and Oleg Negruța (Republic of Moldova). The article is focused on Chamber Music compositions with Jazz influences, written by Iași authors. The purpose is to create a general presentation and also a structural-interpretive analysis of some works from my personal repertoire, which was actually one of the main criteria of selection. The objects of the research are: highlighting the particularities of the genre and style of contemporary works; presenting the interpretive aspects of the compositions and proposing some personal suggestions and tips. Although the selected works have been initially composed for different instruments and have been played to live audience, they have not presented themselves, so far, as a research subject, and thus have not been analyzed. Taking into consideration this deduction, the novelty and the personal contribution are visible in the scientific research that deals with the autochthonous compositional patrimony. The aspects presented in this article can be used for pedagogical processes and, at the same time, they can behave as a practical method in managing the chosen repertoire.
\end{abstract}

Keywords: chamber music, jazz influences, Iași composers, stylistic-interpretative aspects.

\section{Introduction}

Chamber music has always been a particular genre in the artistic field, requiring a certain audience: select, knowledgeable, demanding, critical, but also eager to listen to new works or to listen again to their favorite works, communicated through an artistic act which can't be associated with dilettantism.

\footnotetext{
*aurisim_pian@yahoo.com
} 
Because the concept of chamber music has evolved over time, it has always provided the opportunity to experiment. The search for new ways of expression, new stylistic procedures and new sounds, the desire to use new emission techniques were a constant concern for composers, and it is not surprising that at the confluence of the $20^{\text {th }}-21^{\text {st }}$ Century, the interest in this genre of both Romanian composers and Bessarabia composers has especially grown. Through their compositional contributions, the repertoire of the chamber ensembles is frequently enriched, this fact being reflected also in the composition of the chamber ensembles, made at the present time also by the combination of some heterogeneous instruments in terms of construction and timbre. A significant role in this direction lies also with the sources of inspiration to which they are appealing. And one of the sources, which offers precious rhythmic, coloristic, melodic, harmonic, even architectural-sound suggestions, turns out to be jazz, which has contributed to the development of an original musical synthesis system and of new genres: symphonic jazz and chamber music jazz. This system is distinguished by the expansion of the sound universe achieved by the widening of the spectrum of compositional procedures and techniques, by the use of new instrumental combinations, both in the ensemble and in solo music (usually with the predominance of wind instruments). There is also a new relationship between the elaboration of the work and the improvisation style, generated by the promotion of a new musician-performer type, who combines in a creative, original manner the two sides of the musical act: composition and performance.

In Romanian music, following the great example of some famous American or European composers (George Gershwin, Darius Milhaud, Maurice Ravel, Igor Stravinsky, etc.), there are many examples where contemporary composers felt the inner need of renewal by using jazz influences and transposing its spirit into valuable symphonic or chamber works. It is important to mention the Romanian composer who gave a first impetus in this field and acquired important achievements in the field of symphonic and chamber jazz - Richard Oschanitzky, whose disciple was another great composer - Sabin Pautza. A great admirer of Richard Oschanitzky, who has been among his idols, is also the Romanian composer from Iaşi, Romeo Cozma. In the creation of the two composers - Sabin Pautza and Romeo Cozma - the influence of jazz has a particular significance.

Being attracted to jazz in my piano performances, I discovered in the genre of chamber music with jazz influences, signed by authors from Iaşi, some valuable works that I have included in my personal repertoire: Grand Concert Duo for clarinet and piano by Sabin Pautza and Balkano Dance Trio for clarinet, horn and piano by Romeo Cozma, works that have had a great impact on the public, achieving a real success. 


\section{Sabin Pautza - Grand Concert Duo for clarinet in Bb and piano}

A composer and conductor with an impressive career in the Romanian and international musical life, professor and manager, Sabin Pautza has a biography that is distinguished by his dedication, leading to a remarkable creation in terms of originality and mastery. Polyvalent musician, Sabin Pautza engineered various sounds, either in works where the subtle and masterful transfiguration of Romanian folklore has universal resonances, or in works characterized by "neoromantic with blues or jazz intonations, echoes from Bartok, Stravinsky or Shostakovich" (Sandu-Dediu, 2017, p. 17), but also in entertainment music or musicals and theater music.

Born on February 8, 1943 at Câlnic - Reșita, Sabin Pautza was formed at the "Ciprian Porumbescu" Conservatory in Bucharest, graduated in 1965, having as mentors Marţian Negrea, Tudor Ciortea, Dumitru D. Botez, Emilia Comişel, Ştefan Niculescu, Aurel Stroe and Ion Dumitrescu (composition), but especially Marin Constantin (founder and conductor of the Madrigal choir). It is not to be omitted the fact that Sabin Pautza has been orchestrating songs from the period of his studies, under the guidance of his older colleague, the famous jazz musician Richard Oschanitzky.

In 1970, he specialized in composition and conducting at the Accademia Chigiana in Siena, Italy, having as mentors Franco Donatoni, Bruno Maderna and Franco Ferrara. He was an assistant professor and lecturer at the "George Enescu" Conservatory in Iaşi, between 1966 and 1984, where he taught harmony and composition. He was also conductor of Animosi Choir and of the Students Symphony Orchestra - with these two ensembles having successful concerts in Romania, Poland and Germany.

After receiving a scholarship from the Union of Composers, Sabin Pautza leaves for the United States in 1984, where he remains onwards. Here, following a very competitive contest, he was appointed artistic director and principal conductor of the oldest New Jersey orchestra, The Plainfield Symphony. "According to his testimonies, Sabin Pautza believes that his true debut on the American continent occurred in 1985, when in the prestigious Carnegie Hall in New York, he presented himself with a double status: conductor at the New York University Symphony Orchestra and composer. The Plainfield City Hall named Sabin Pautza an Honorary Citizen and Emeritus Conductor for life of the Symphony Orchestra, deciding that May 7, 2007 was Sabin Pautza Day in Plainfield, a recognition of his 20-year-old service for the community and for the prestige of this American city." (Gorghiu, 2017)

As a conductor, Sabin Pautza led some of the most famous orchestras in Europe, America and Australia on famous scenes: Carnegie Hall in New York, Santa Cecilia in Rome, "Frédéric Chopin" in Warsaw or Sydney Philharmonic Hall. He also held courses at various American universities, including the 
Atlanta Institute of Music, the New York University, St. Rose University Albany, New York, Rutgers University, New Jersey. He was a professor at Emanuel University in Oradea.

Sabin Pautza's name appears in Who's Who in Music (Cambridge, 1980, 1984, 1990, 1996), as well as in the 2000 Notable Americans volume, published by the American Biographical Institute. He is a member of the Union of Composers and Musicologists of Romania, of ASCAP (American Composers Union), member of GEMA (German Composers Union) and honorary member of the Bureau of Counselors of the American Biographical Institute. In 1996 he received the Honorary Title of Doctor in Music at the London Institute for Applied Research. Sabin Pautza also obtained the title of Doctor in composition at the "Gheorghe Dima" Academy in Cluj-Napoca. He is Doctor Honoris Causa of "Valahia" University of Târgovişte and Doctor Honoris Causa of "Eftimie Murgu” University in Reșita. Sabin Pautza is also an honorary citizen of Plainfield, New Jersey, Reşiţa and Caraş-Severin. From 2014, the International Contest and International Festival of Piano Performance and Composition "Sabin Păutza", is being held at Reșiţa, organized by the Society for Culture "METARSIS". Also, the High School of Art in Reșita is named after him. The Swift Music Group in the United States has edited his Opera Omnia series on CD, 15 of them being printed up until now. Also, the San Nicobian music publishing house in New York has exclusively published his scores.

Through his musical creation, regardless of the styles he traversed, the composer Sabin Pautza knew how to impose his authentic voice, his works being valued both by performers and public and awarded both in Romania and in America: the "George Enescu" Award, Romanian Academy Award, Romanian Composers' and Musicologists' Prize, Romanian Television Grand Award, Salt Lake City International Contest Award - Utah, American Organization ASCAP "Rudolf Nissim" Prize, the grand prize "Doctor Martin Luther King Jr." (for the composition of Chimes). The most recent distinction The Royal Decoration "Nihil Sine Deo" - was given to him by the Royal House of Romania in October 2016.

Even though he lived 33 years in America, Sabin Pautza says everywhere: "I am not an American composer, I am a Romanian composer forced to live in exile. Home is home. At Reșita” (Chițan).

Although home is Romania, Reșiţa, Sabin Pautza confesses that "America has opened other windows, other doors" (Chițan), because there he had to write music for Americans, for their tastes: "I mean music that is rather oriented towards jazz, gospel, so as to be welcomed there" (Chițan). His music was described by a critic from New York Times in a review as a music that "could be seen it was written by a Romanian." (Chițan). When asked how he realized that, the authour confessed that "he was a colleague with Lipatti, he 
met Enescu. I could not hide, Pautza says, there were some things out there that betrayed me". Still, one might say that Pautza has absorbed avidly elements of American music, creating a musical language characterized by premeditated simplicity, transparency and a pronounced clarification of means of expression, which is clearly seen in his works inspired by black-spiritual and jazz folklore; even the great Leonard Bernstein entrusted him pages of the music of his Broadway shows, including the West Side Story, to be re-orchestrated in the form of suites that can be performed in concert halls.

The works of Sabin Pautza, such as: Divertissement No. 2 (Silent movie a rag time, Bossa-Nova, Charleston, Tango, Fiesta), Divertissement No. 3 (Capriccio, Ragtime, Cha-Cha) that can be performed in different instrumental and orchestral versions, the exceptional Concerto for Saxophone and Orchestra, as well as the large number of vocal and choral works in gospel style etc. prove a colourful writing, revealing the talent, the grace with which their author knew how to emphasize sounds, harmonies and rhythms of jazz-aesthetic inspiration. These works also show a richness of orchestration with a wide range of wind instruments and percussion, as one may observe in another musical work, composed with the same features - Grand Duo for clarinet in $B b$ and piano $^{1}$ - dedicated on February 14, 2013 to Professor Doru Albu and his disciples.

Grand Duo for clarinet in Bb and piano, is distinguished by the swing characteristic of American jazz music, made especially by the syncopated rhythm that imposes the specific rhythmic pulse with special accents which are imposed on syncope formulas or half accentuated and non-accentuated beats.

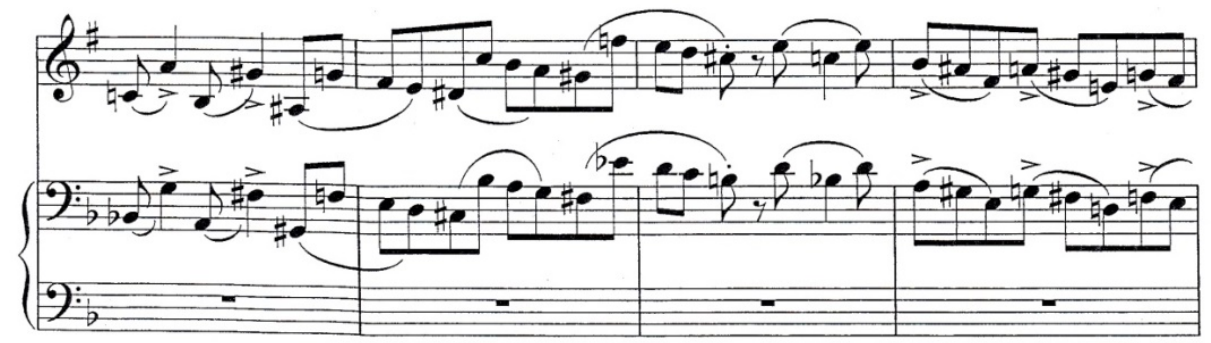

Fig. 1 Sabin Pautza, Grand Duo pentru clarinet în Sib și pian, mm. 12-15

Composed in $d$ minor, initially in the $4 / 4$ time signature, during the musical discourse, besides synchronic rhythmic formulas and accents, in order to impose and sustain the syncopated rhythm, the author often uses alternating time signatures, generating a binary-ternary succession.

\footnotetext{
${ }^{1}$ A fragment of Grand Duo by Sabin Pautza was played at the show Nichita 100\% iubire [traducere] which was realised together with the actors Octavian Jighirgiu și Laura Bilic and presented to audiences in Iași, Suceava, Vatra-Dornei, Bistrița-Năsăud and Chișinău.
} 
For example, in bar no. 23, when the solo piano begins alternating the $3 / 4$ $-2 / 4$ time signatures, but stays in the fifth on the 3/4 ternary rhythm, it imposes even more vigorously at this moment the syncopated rhythm:

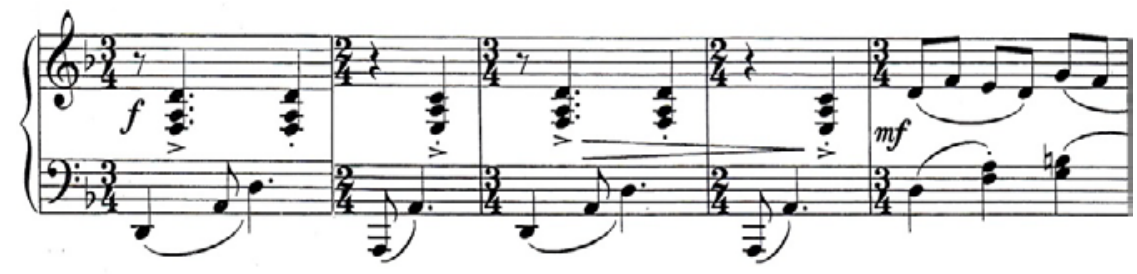

Fig. 2 Sabin Pautza, Grand Duo pentru clarinet în Sib și pian, mm. 23-27

The alternation of ternary-binary rhythms is maintained throughout the musical discourse, which implies a special attention from the soloists, including the syncopes and accents which are prevalent throughout the whole musical discourse. It is imperative, for example, that the unison in the Duo's debut be well studied by the performers, so even from the first quavers they can achieve that swing movement indicated by tempo.

After the extensive Introduction realized in unison by the clarinet and piano on the right hand (in the deep register), at bar 27 starts the ternary exposure of the Refrain Theme - a symmetrical phrase, composed of 2 segments of 4 bars, played in quasi-unison by the clarinet and the piano on the right hand, on which the whole discourse is built; we could appreciate the "original” Rondo-Sonata, with the following structure:

Introd. (M.1-22) - trans. (mm. 23-26) - A (Refrain) (mm. 27-34) - B (Couplet) (mm. 35-90) - A (Refrain) (mm. 91-106) - trans. (mm. 107-115) C (Development) (mm. 116-176) - trans. (mm. 177-180) - Recapitulation Introd. (mm. 181-187) - trans. (mm. 188-193) - A (Refrain) (mm. 194-201) - B varied (Couplet) (mm. 202-289) - A (Refrain) (mm. 290-305) - D (Dev.) (mm. 306-417) - trans. (mm. 418-425) - A (Refrain) (mm. 426-433) - B varied (mm. 435-489) - A (Refrain) (mm. 490-497) - trans. (mm. 498-504) Final (Coda) (mm. 505-601).

The Refrain theme, with a simple but syncopated melody, consists of a symmetrical phrase of 8 bars, with two equal segments in size. The first segment ends on the dominant chord, $A$ Major: 


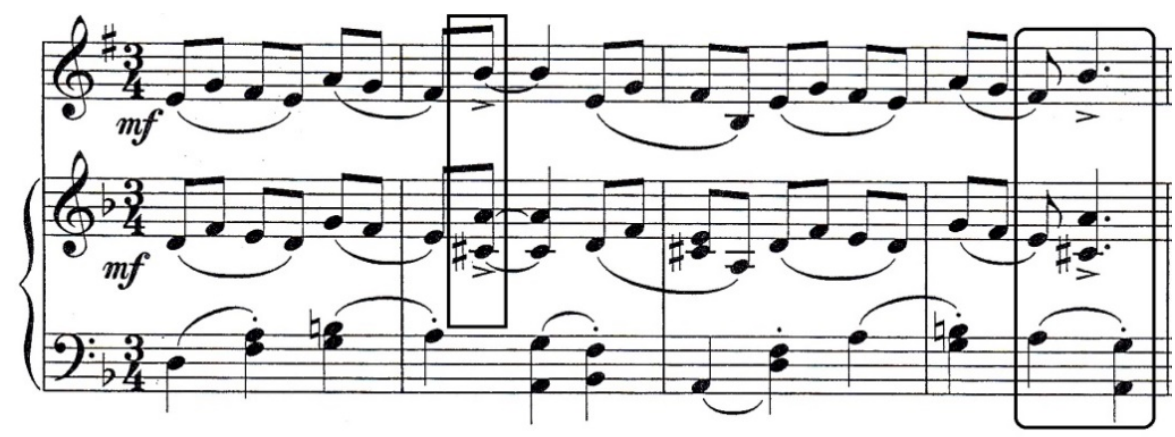

Fig. 3 Sabin Pautza, Grand Duo pentru clarinet în Sib și pian, mm. 27-30

It is repeated identically, with a clear ending on the tonic chord, $d$ minor:

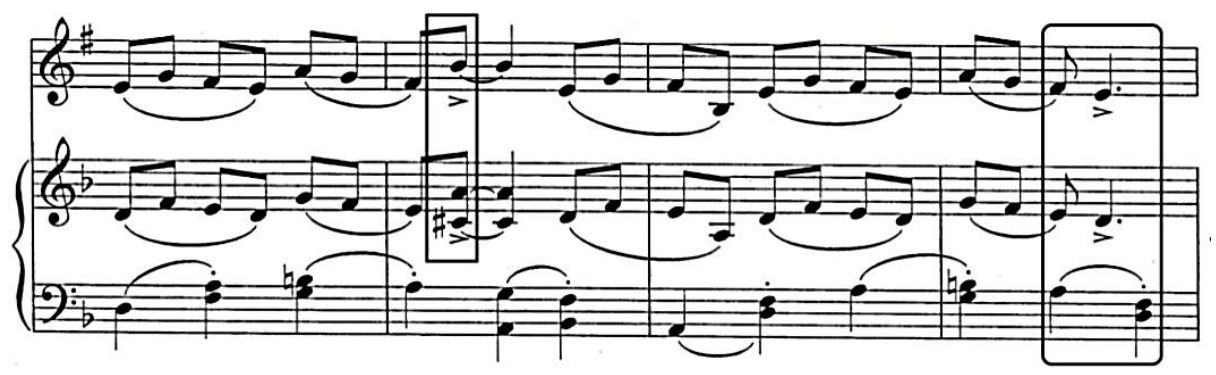

Fig. 4 Sabin Pautza, Grand Duo pentru clarinet în Sib şi pian, mm. 31-34

After the ample introduction of the two instruments: the clarinet and the piano and a moment of transition played by the clarinet, then by the piano, the Exposition section starts by presenting the theme seen above, played by both instruments, which is also the Refrain Theme $-\boldsymbol{A}$, then continues with a $\boldsymbol{B}$ Couplet. In this part, the theme is presented alternately - by the clarinet accompanied by the piano and conversely, as one can see in the two following examples, always preserving the syncopated rhythm:

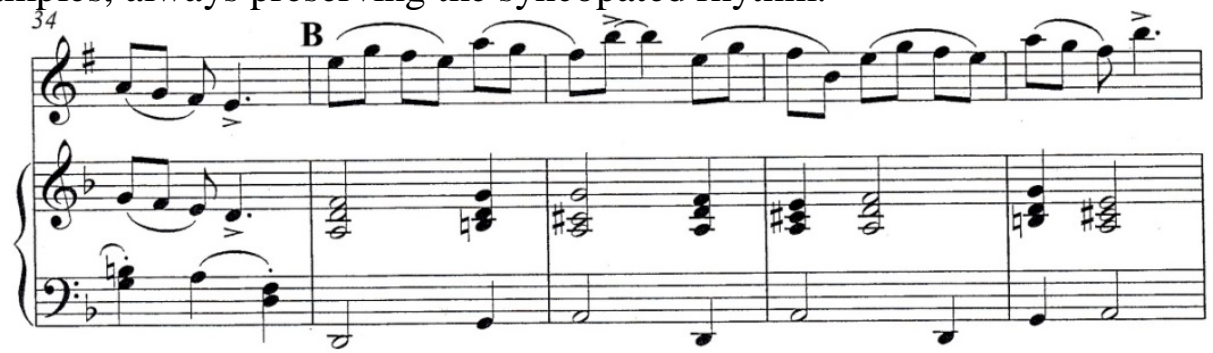

Fig. 5 Sabin Pautza, Grand Duo pentru clarinet în Sib și pian, mm. 34-38, clarinet accompanied by piano 


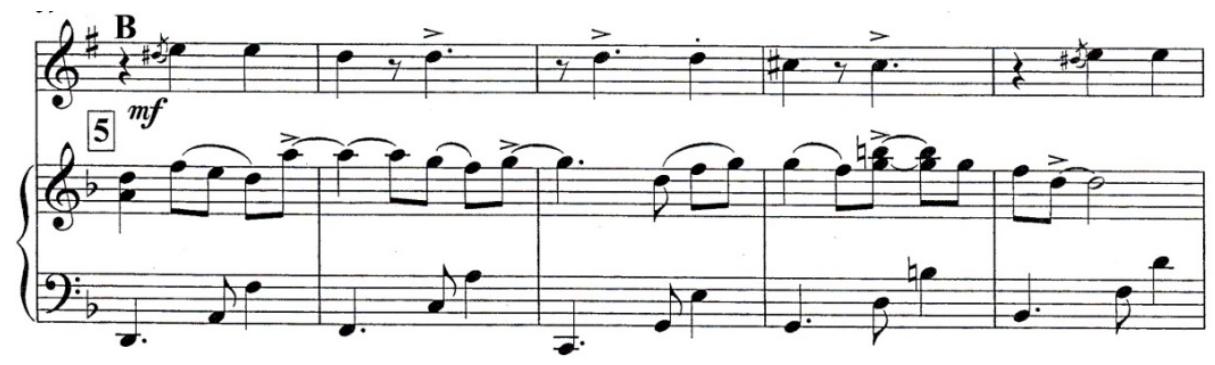

Fig. 6 Sabin Pautza, Grand Duo pentru clarinet în Sib și pian, mm. 39-43, piano accompanied by clarinet

After the Refrain Theme - $\boldsymbol{A}$, again presented in unison with the two instruments and a transition of the clarinet, the $\boldsymbol{C}$ section, - Couplet (bar 116) has the character of a Development based on variations of the motifs presented by both piano and clarinet, through sequencing, rhythmic, harmonic and melodic variations and dialogues between the two instruments. But each of the theme inceptions in the dialogue must be clearly highlighted by each performer.

A very important aspect in playing is the attention to be given to the tempo, because the alternation of moments at different speeds suggests, somehow, the improvisation sensation specific to jazz.

The tempo initially proposed by the author is $\bullet=160$, but after the first acceleration of the solo clarinet (also made in an alternation of time signatures: $3 / 4,2 / 4$ with $4 / 4$ settling) before 4 measures of the 10th reference point, the tempo - becomes $=165$. The pianist has to keep in mind both the change of the time signature $(2 / 4,4 / 4)$ and the rhythmic drawing that requires a precise emphasize of the syncopated pulsation. Also, starting with bar 126, there is a gradual acceleration, reaching the tempo with $\bullet=175$ at bar 130 (the 11th reference point). In fact, the section that begins with number 11 is a more difficult one, because it contains numerous accidentals, cromatisms and dense chords. From the point of view of the ensemble, at the 12th reference point, the musical discourse requires a special attention to performers in terms of dialogue between instruments, in order to highlight certain features of the score.

With 3 bars before number 15 (bar 175), in rallentando poco a poco, the tempo returns to $\bullet=160$. So, there is an oscillation of tempo, in which it is introduced the Meno mosso movement (bar 175) and a short fragment that follows, with.$=145$; in fact, we are talking about a brief dialogue between the piano at the right hand and the clarinet, during 2 bars, followed by the piano's solo intervention, ending on the cesura. 
An interesting fact is that after the developping episode, the author specifies the return to Tempo primo (bar 181), as a false Recapitulation, which also returns the pace of the initial tempo: $\bullet=160$ that is maintained until the end. The Introduction, Refrain $\boldsymbol{A}$ and Couplet $B$, to which it is still applied a short closing with elements from the Refrain A theme in the same way, are continued with a D Couplet (bar 306), which starts with a short clarinet-piano dialogue.

Couplet D (bars 306-425) is a test-piece for both performers because, starting with the 24th reference point, they encounter particular problems, both rhythmically (syncopes, pauses, binary meter alternating with ternary meter) and in the performance of the ensemble, in which the clarinet holds the melodic line and the piano has the accompaniment with drenched chords, with rhythmic values of crotchets or dotted crotchets.

Between the 27th and 32th reference points, the discourse still takes the form of a continuous dialogue between the two instruments, creating a more lyrical, blues-like atmosphere. The return of the Refrain in a wider configuration emerges for the moment also that specific swing. At 37, suddenly appears, again, in Meno mosso, a tempo slowing: $•=145$, then, after a rit. in the solo exhibition of the clarinet, at 38 (bar 504), the musical discourse is continued by the solo piano with a large exposition, this time in binary beat $12 / 8$ (.. = 110). This fact imposes another rhythm at the Ending, in a blues balance whose debut is entrusted to the pianist, who must emphasize the syncopations very well at bars 508-510.

In the end, the pace is accelerating in a dynamic growth - poco a poco, crescendo molto - from $\boldsymbol{m p}$ to $\boldsymbol{f}$ - $\boldsymbol{f f}$ - $\boldsymbol{f f f}$, which the two performers have to handle with care, both in terms of sound intensity and rhythm.

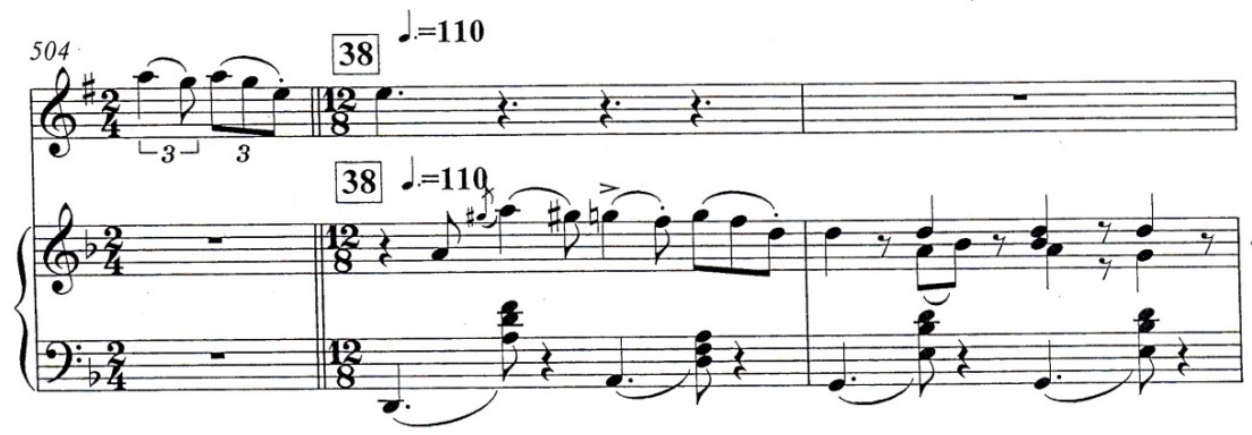

Fig. 7 Sabin Pautza, Grand Duo pentru clarinet în Sib și pian, mm. 504-506

All the musical indications for rhythm and dynamics, which the author has specifically mentioned and must be observed, have the role of contributing to the full value of this entertaining music, so it is necessary for the two soloists to take into account the placement of every accent, the expression legatos, the dynamic alternations and tempo oscillations. Nevertheless, the flavor of this 
work is amplified by the short dialogues between clarinet and piano, the rhythmic support of the piano or the small glissandos and the slap tongue and the multitude of appoggiaturas in the melodic discourse of the clarinet.

\section{Romeo Cozma - Balkano Dance Trio}

Romeo Cozma is today a reference name in Romanian jazz, being the first musician in Romania to receive the title of Doctor in Music in the field of jazz, obtained in 2004 at the "Gheorghe Dima” Music Academy in Cluj-Napoca with the theme Ipostaze ale jazz-ului în creația muzicală proprie [The Aspects of Jazz in my own Musical Creation].

Born in November 13, 1955 in Bucharest, Romeo Cozma made his first steps towards a career in the musical field by studying the piano at "Octav Băncilă" High School of Arts in Iaşi. He then attended the courses of Composition, Musicology, Conducting and Pedagogy at the "George Enescu" University of Arts in Iași, specializing in musical pedagogy and composition under the guidance of renowned masters of Romanian music such as Vasile Spătarelu, Anton Zeman, Sabin Pauțza, who had an important influence on his career.

Being fascinated by jazz music since high-school, a musical direction that is realized through a different type of musical language than the one learned in school, based on improvisation and inspiration, but also on solid knowledge and professionalism, Romeo Cozma passionately dedicated himself to this genre, having idols such as Chick Corea, Herbie Hancock, Dave Brubeck and Richard Oschanitzky.

A representative figure in the world of Iași's music, Romeo Cozma has been a talented pianist, composer, arranger and leader of the Studio-Jazz-Quartet, and his presence on various stages in Romania and abroad (Republic of Moldova, Germany, France, Austria, Italy, Belgium, Sweden, United States of America, etc.), have had a great impact, surprising the audience through creativity and also through a variety of formulas undertaken, from piano solo works to jazz combo and big band, but also as solo pianist alongside symphonic orchestras.

In 1979, one month after the passing of the great jazz musician Richard Oschanitzky into the world of shadows, one of the idols he had in his musical training, Romeo Cozma created a new department in the Students' House in Iaşi - the Jazz Music Club named "Richard Oschanitzky" - whose purpose was to promote both the creation of the great composer and the modern Romanian music, but also to develop skills in this field for students from all universities in Iași.

Since 1991 Romeo Cozma is a member of the Union of Composers in Romania, who also granted him two awards in 1995 and 1999 for his compositions in jazz music.

Currently, Romeo Cozma is PhD. Professor at the National University of Arts "George Enescu" Iași, where he has established the Jazz and Modern 
Music Specialization in the Music Department since 1994, many of the graduates of this section succeeding to become national and international performers; his didactic activity for almost three decades has also been involved in editing important jazz music volumes, such as: Universul muzicii de jazz [The Universe of Jazz Music], Stiluri de compoziţie în muzica de jazz [Composition Styles in Jazz Music], Teme de jazz [Jazz Themes] - vol. I, and Teme de jazz [Jazz Themes] - vol. II which is still being written.

With a prodigious activity in the field of teaching and performance, Romeo Cozma is also remarkable in composition, reaching an impressive number of works, in various genres: jazz music, pop music, electronic music, stage music, orchestral works and chamber music, etc. Blues, Fantasy in Swing Rhythm, The Colors of Tears, Waltz, Balkano Dance, Gravity, Samba, Nostalgia, The Dream of Sheherezada, Negro - Spirituals Suite, Fantasy for Clarinet Quartet, Piano Sonata, Jazzissimo for Viola Ensemble, Orchestra Divertimento, all are just a part of the scores he gave life to. We also remind some of his edited CDs: Solo piano ... in Paris, Blue Note and Tribute to Dave Brubeck, where one may find some of his original creations, his mature artistic achievements, which have synthesized experiences lived in a sensible and imaginative, meditative and exuberant music.

Originally conceived for the clarinet quartet with the title Orient Express, the Balkano Dance Trio was subsequently arranged for a heterogeneous trio: clarinet, horn and piano, to be performed in the 54th edition of the International Chamber Music Festival in Plovdiv, Bulgaria. ${ }^{2}$

The song is conceived in a tristrophic form: A - B - A'- Coda, developed as follows:

\section{A}

Introduction (mm.1-4) - a (m.5-18) - $\mathbf{a}_{1}$ (m.19-29) - $\mathbf{a}_{2}$ (mm.30-43) - $\mathbf{a}_{3}$ (mm.44-54)

B

transition (mm.55-59) - b (mm. 60-73) - $\mathbf{b}_{1}(\mathrm{~mm} .74-83)-\mathbf{b}_{2}(\mathrm{~mm} .84-96)$

$\mathbf{A}^{\prime}$

transition (mm.97-105) - a' (mm.106-118) - a' ${ }_{1}(\mathrm{~mm} .119-130)-\mathbf{a}_{2}(\mathrm{~mm} .131-144)$ $\mathbf{a}_{3}(145-1152)$

Coda (mm.153-157)

The element that draws attention from the very beginning after the piano introduction is the Theme of the clarinet in $\boldsymbol{m p}$, on which the whole melodic

\footnotetext{
2 The Balkano Dance Trio was performed on June 15, 2018, at the International Chamber Music Festival in Plovdiv, Bulgaria, in a recital performed at the Ethnographic Museum by the trio Mihai Ailenei, clarinet, Petrea Gâscă, horn and Aurelia Simion, piano. References to this recital, signed by Paunova-Tosheva, appeared in the article 54-tii Mejdunaroden festival na kamernata muzika $v$ Plovdiv, published in the Bulgarian Union of Bulgarian Musicians and Dancers Muzikalini horizonti, no. 7/2018, pp. 13-14.
} 
discourse will be built, a theme with a simple melodic line, conceived on near scale degrees, with accents and syncope in the time signature marked as 7/8, in aksak rhythm, which gives that Balkan-Oriental sonority:

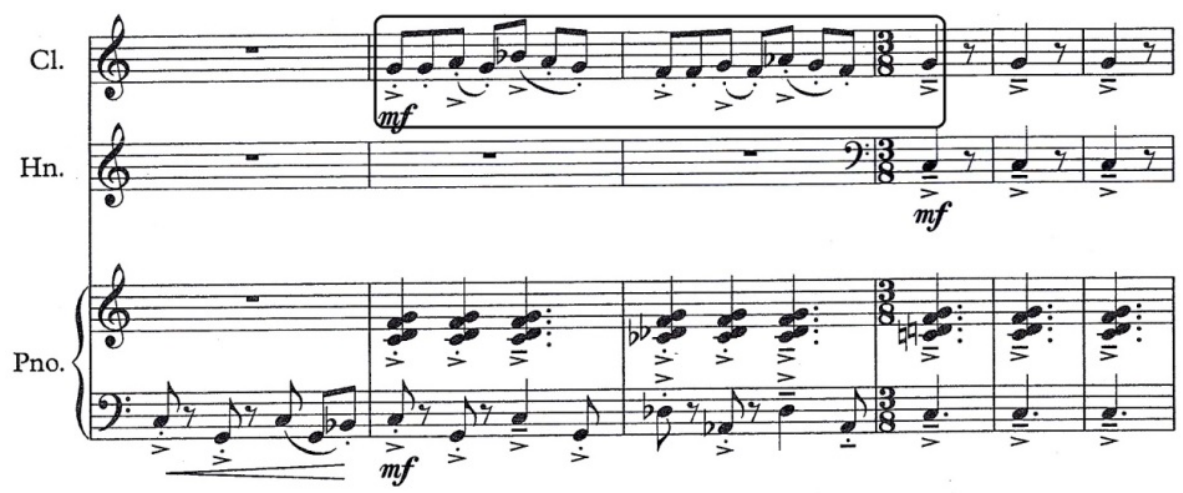

Fig. 8 Romeo Cozma, Balkano Dance Trio, mm. 4-9

The work starts in $7 / 8$, at a fast metronome indication of $\bullet=170$, which is maintained throughout the melodic discourse, the author also using frequent exchanges of time signatures: $7 / 8-3 / 8-4 / 8-4 / 4$. In the Finale section, it is required an intense acceleration in 7/8.

A distinctive character of the work is given by the strongly emphasized rhythms in some particular moments, containing tenuto accents indicated in the score of all three instruments, usually inserted in the $\mathbf{A}$ and $\mathbf{A}^{\prime}$ sections, between the solos of the clarinet. These moments are written in the 3/8 and 4/8 time signatures, which predict the $7 / 8$ combination, in which all these solos of the clarinet are presented. It is also important to mention the features of the melodic level performed by clarinet, which usually contains accents, staccato-legato sounds, mordentos and sometimes short glissandos, which give that specific oriental sonority:

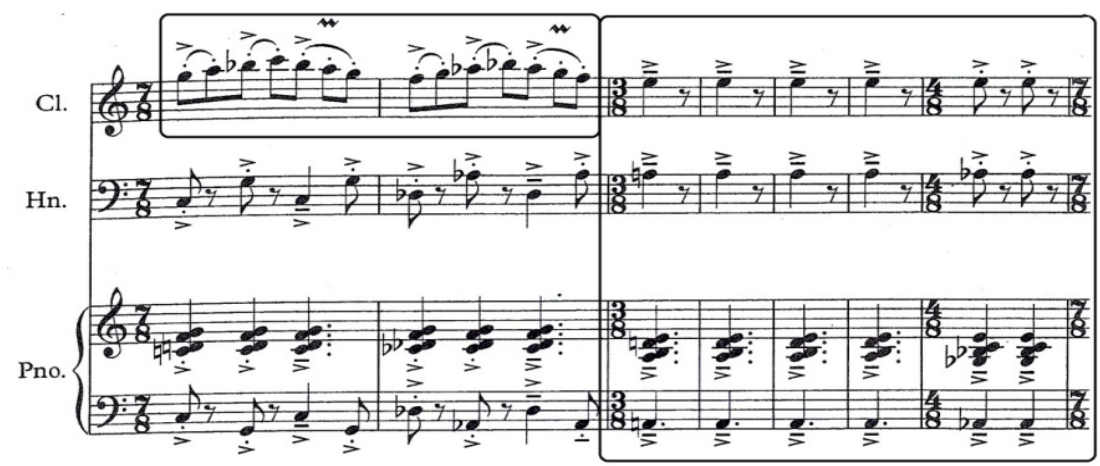

Fig. 9 Romeo Cozma, Balkano Dance Trio, mm. 10-16 
From bar 60, when the $\mathbf{B}$ strophe begins, in the solo section of the piano, the author asks for an accentuated tenuto, with a lot of pedal. What characterizes this section is the dialogue involving all three instruments. However, the two moments of bars 71 and 91 must be taken into consideration, in which the piano and the clarinet must play together a chord that requires a precise attack. At the same time, in solo interventions of the piano conducted between bars 74-78 and 84-88, the syncopes should be played with more ease. At bar 95, before the transition to section $\mathbf{A}^{\prime}$, one has to easily overcome that difficult moment at the rhythmic melodic level and for the main melodic line which must be accomplished in perfect timing by the two wind instruments:

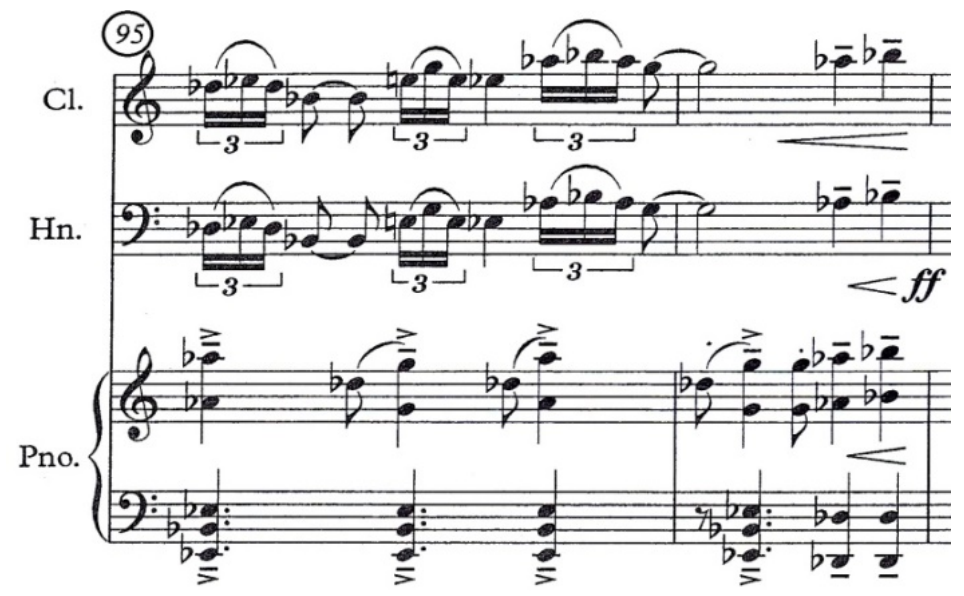

Fig. 10 Romeo Cozma, Balkano Dance Trio, mm. 95-96

The trio's Coda, with an intense accelerando and a crescendo to $\mathrm{ff}$, is finalized on a last chord that has to be played with accentuated $s f z$.

Romeo Cozma's Balkano Dance Trio, a jazz-style work with Balkan-Oriental influences, has great success on the stage with every performance, in both versions as the clarinets quartet (Orient Express) and the trio for clarinet, horn, piano.

\section{Conclusions}

By approaching these two jazz inspired works, which belong to the composers Sabin Pautza and Romeo Cozma, both connected to Iaşi (works included in the personal repertoire), I wanted to achieve, in addition to an overview of the authors of the two works (Grand Duo and Balkan Dance Trio) also an emphasis on the particular features of the genre and style of the works. The structural-interpretive analysis and the elucidation of some performance issues of the mentioned works, as well as the personal suggestions for solving some technical difficulties or recommendations regarding the musical 
expressiveness, I consider them a practical support in approaching the analyzed repertoire, also used in the process of teaching.

\section{References}

Chiţan, S. Compozitorul și dirijorul Sabin Păutza: „America mi-a deschis alte ferestre şi alte uși însă acasă este Reșiţa [Composer and conductor Sabin Păutza: „America has opened new windows and doors, but home is Reşiţa"], retrieved from https://adevarul.ro/cultura/arte/compozitorul-dirijorul-sabin-pautza--america-mi-adeschis-alte-ferestresi-alte-usi-insa-acasa-este-resita

Cozma R. (2006). Universul jazz-ului [The Universe of Jazz]. Iași: Editura Artes.

Cozmei, M. (2010). Existențe și împliniri. Dicționar biobibliografic [Existence and fulfillment. Biobibliographic dictionary]. Iași: Editura Artes.

Gorghiu, A. Sabin Pautza diagnosticat de americani ca workaholic [Sabin Pautza diagnosed by Americans as workaholic], retrieved from Cotidianul.ro, 27 March 2017, https://www.cotidianul.ro/sabin-pautza-diagnosticat-de-americani-caworkaholic/

Sandu-Dediu, Valentina (2017). Prolog [Prologue], in Sabin Pautza, Maestrul [Sabin Pautza, The Master], Daniela Caraman Fotea (Ed.). București: Editura Palimpsest. 